\title{
Prevalence of trachoma and associated factors in students from the Jequitinhonha Valley, Minas Gerais, Brazil
}

\author{
Evanildo José da Silva ${ }^{[1]}$, Daniela Porto Pereira ${ }^{[1]}$ João Octávio Augusto Murta Ambrózio ${ }^{[1],}$ \\ Laiara Morais Barboza ${ }^{[1]}$ Vivian Ladeira Fonseca ${ }^{[1]}$ and Antônio Prates Caldeira ${ }^{[2]}$
}

[1]. Universidade Federal dos Vales do Jequitinhonha e Mucuri, Departamento de Medicina, Diamantina, MG, Brasil.

[2]. Universidade Estadual de Montes Claros, Departamento de Medicina, Montes Claros, MG, Brasil.

\begin{abstract}
Introduction: Trachoma is the leading cause of blindness in the world, especially in undeveloped countries, due to its association with poor socioeconomic and sanitation conditions. This study aimed to estimate the prevalence of trachoma among students from the Jequitinhonha Valley, Minas Gerais, one of the poorest regions in Brazil, and to identify associated factors. Methods: This is a crosssectional study that utilized clinical evaluation and a socioeconomic questionnaire applied to a random and representative sample of elementary school students from the Jequitinhonha Valley, Minas Gerais, Brazil. Participants underwent conjunctival scraping and direct immunofluorescence was used to confirm the presence of the bacteria. Five or more elementary bodies in the conjunctival scrape was considered a positive result. In the study, $36.6 \%$ positive samples were detected. A culture of the conjunctival scrape, considered to be the "gold standard", was not performed due to cost and complexity. Bivariate analyses were performed, followed by binary logistic regression analysis to define the associated variables. Results: In the present study, 478 students comprised the sample. The prevalence of trachoma was $6.3 \%$ and was higher among students who lived in unfinished houses (no plastering, painting, flooring, and unfinished bathrooms) (OR, 2.27; 95\% CI, 1.12-6.48) without sewage systems $(\mathrm{OR}=9.49 ; 95 \% \mathrm{CI}=3.52-25.60)$ and studied in rural areas (OR, 3.37; 95\% CI, 1.53-7.35). Conclusions: The prevalence of trachoma among the students aged 7 to 16 years old, from public and private schools, is not negligible and is especially associated with inadequate living conditions.
\end{abstract}

Keywords: Chlamydia trachomatis. Neglected disease. Epidemiology.

\section{INTRODUCTION}

Trachoma is the leading cause of preventable infectious blindness in the world. It is endemic in some developing countries and belongs to the group of neglected tropical diseases, according to the World Health Organization ${ }^{1}$. It is an infectious disease caused by the bacterium Chlamydia trachomatis and its development is associated with poor socioeconomic and sanitation conditions ${ }^{1-4}$.

Currently, it is estimated that 192 million people live in endemic areas and 1.6 million are affected by the disease, with 400,000 becoming irreversibly blind ${ }^{5}$. In the 1990s, under the leadership of the World Health Organization (WHO), the "Alliance for the

\footnotetext{
Corresponding author: Evanildo José da Silva.

e-mail: evanildosdl@yahoo.com.br

(D) https://orcid.org/0000-0001-5324-2642

Received 6 April 2020

Accepted 27 July 2020
}

Global Elimination of Trachoma by 2020 " was established, to which Brazil is a signatory ${ }^{4,5}$.

In Brazil, during the period known as the "economic miracle" (1950s to 1970s), there was a significant decrease in the detection of trachoma, suggesting that this disease was no longer a public health problem, which led to the misguided belief that the disease had been eradicated ${ }^{6,7}$. However, epidemiological research shows that trachoma persists in the country as a public health problem, and should be considered as a possible diagnosis when patients present with acute and/or chronic conjunctival inflammation ${ }^{8-12}$.

In the last national survey carried out in 1,156 municipalities, in all regions of Brazil and involving 119,531 students, a prevalence of $5 \%$ of trachoma was observed. Some locations had a higher prevalence, such as $7.9 \%$ in Acre and $8.7 \%$ in Ceará. Considering the variables evaluated, significant differences were found between students of rural and urban origin and between children under five years old and older age groups. There was a higher prevalence among students from rural areas and lower age groups. There was no significant difference between men and women?. 
A survey of students from the state of Roraima revealed an average prevalence of $4.5 \%$, and some municipalities had a prevalence greater than $10 \%$. The researchers conducted the study with 6,986 elementary and high school students, with an average age of 9.2 years. Among the variables studied, a significant difference was found between students from rural areas and aboriginal communities in relation to those from urban areas ${ }^{10}$. In a study carried out in the countryside region of São Paulo, there was greater involvement of students living in suburbs and intermediate regions of the city compared to those residing in the central region ${ }^{11}$.

The Jequitinhonha Valley, located in the Northeast region of Minas Gerais, is considered one of the poorest regions of Brazil, and there are no studies with a representative sample addressing the prevalence of trachoma in students in this region, where a considerable contingent of people live in rural areas. Therefore, this research aimed to determine the prevalence of trachoma and associated factors among elementary school students in the Jequitinhonha Valley, Minas Gerais.

\section{METHODS}

This is a cross-sectional study, whose target population consisted of elementary school students. The study setting was the Jequitinhona Valley, Northeast of Minas Gerais. The region has 29 municipalities and is one of the poorest in Brazil ${ }^{13}$.

For sample selection, we used the cluster sampling technique, where each of the elementary schools was considered as one cluster. School selection was done randomly by drawing lots. Lastly, a group of students was drawn, where all the students were eligible for the study.

For the sample size calculation, a confidence level of $95 \%$, an estimated prevalence of $6.0 \%$, and a sampling error of $2.5 \%$ were considered. The value found was multiplied by a correction factor for the design effect of 1.5, considering cluster sampling.

Prior to data collection, the selected schools were informed of the study and supported its implementation. The students and their legal guardians, after formal communication and agreeing to participate in the research, signed the terms of consent and answered the questionnaire containing information on socioeconomic aspects about the participants and housing conditions.

Data collection was conducted from January to December 2018 by one of the researchers, an ophthalmologist with experience in trachoma.

Clinical examination was performed using a 2.5D magnifying glass and an eyelid eversion maneuver to identify the characteristic lesions. Cases with clinical signs were considered positive according to the WHO criteria, which suggests that diagnosis should be given when there are at least two of the following clinical signs:

- follicles in the upper tarsal conjunctiva

- limbal follicles, also called Herbert's pits

- typical conjunctival scar, which may be vertical and/or horizontal

- upper limb pannus, which corresponds to the invasion of neoformed blood vessels
All students identified as having a positive result underwent conjunctival scraping. The material collected was sent for laboratory analysis and then individuals were referred for treatment and free monitoring by one of the researchers, an ophthalmologist. In addition, subjects were also offered eye evaluation and treatment as needed. Direct immunofluorescence was the test used to confirm the presence of the bacteria in the community. This test, although not very sensitive, has high specificity for trachoma, in addition to practicality and low cost. The presence of five or more elementary bodies in the conjunctival scrape was considered a positive result.

All children and adolescents regularly enrolled in elementary school were included in the study. Children and adolescents who were not at school on the data collection day, and/or did not present the completed socioeconomic questionnaire, were excluded from the study.

Data were processed with the support of the Statistical Package for the Social Sciences software, Version 22.0 (IBM Corp., Armonk, N.Y., USA). Descriptive analyses were initially performed and then bivariate analyses were conducted using the chi-square test between the characteristics of the study group and the presence of trachoma. Variables that were statistically associated with a level of $\geq 20 \%$ $(\mathrm{p}<0.20)$ were evaluated jointly by binary logistic regression.

All ethical aspects were considered and the procedures followed were in accordance with the ethical standards of the Ethics Committee of the Universidade Estadual de Montes Claros (UNIMONTES), and in accordance with the principles of Declaration of Helsinki, 1964. Participants and their families were assured of anonymity and confidentiality.

\section{RESULTS}

A total of 478 children and adolescents, aged 7 to 16 years, were examined. Most of the students evaluated were female $(60.5 \%)$ and the mean age was 11.5 (Standard Deviation [SD] 2.4) years. Regarding the type of school and location, public schools and schools in the central regions of urban areas predominated. Thirty cases clinically diagnosed as trachoma were identified, corresponding to a prevalence of $6.3 \%$, all of which were classified as follicular inflammatory trachoma. The direct immunofluorescence laboratory test detected $36.6 \%$ positivity. Further details are described in Table 1.

Table 2 presents the characterization of the students' housing conditions. Almost all respondents lived in their own homes $(83.3 \%)$ which were finished (86.8\%). Approximately one-third of households were not provided with a sewage system (33.7\%). Although almost all families had access to electricity, 20.5\% did not have an electric shower. This information is important for assessing socioeconomic and hygiene conditions.

Table 3 presents the results of bivariate analyses for the association between demographic and social characteristics and the presence of trachoma among the students. All covariates related at $p$ $<0.20$ to the outcome were jointly evaluated by logistic regression.

Table 4 presents bivariate analyses results. Similar to the analysis of demographic and social data, all covariates related at $\mathrm{p}<0.20$ were jointly assessed by logistic regression. 
TABLE 1: Demographic and social characterization of students in the Jequitinhonha Valley region, Minas Gerais, Brazil, 2018.

\begin{tabular}{|c|c|c|c|c|c|}
\hline Variable & (n) & $(\%)$ & Variable & (n) & $(\%)$ \\
\hline Gender & & & Property type & & \\
\hline Male & 189 & 39.5 & Own property & 398 & 83.3 \\
\hline Female & 289 & 60.5 & Rented property & 67 & 14.0 \\
\hline Age & & & Living with relatives & 13 & 2.7 \\
\hline$\leq 10$ years & 167 & 34.9 & Property Characteristics & & \\
\hline 11 to 13 years & 204 & 42.7 & Finished house & 415 & 86.8 \\
\hline$>13$ years & 107 & 22.2 & Unfinished house* & 63 & 13.2 \\
\hline Current school grade & & & Sewage system & & \\
\hline $1^{\text {st }}$ to $5^{\text {th }}$ grade & 193 & 40.4 & Yes & 317 & 66.3 \\
\hline $6^{\text {th }}$ to $9^{\text {th }}$ grade & 285 & 59.6 & No & 161 & 33.7 \\
\hline School type & & & Bathroom inside the house & & \\
\hline Municipal & 179 & 37.4 & Yes & 468 & 97.9 \\
\hline State & 299 & 62.6 & No & 10 & 2.1 \\
\hline School location & & & Electric shower & & \\
\hline Urban area (central region) & 253 & 52.9 & Yes & 380 & 79.5 \\
\hline Urban area (suburban region) & 93 & 19.5 & No & 98 & 20.5 \\
\hline Rural area & 132 & 27.6 & Water & & \\
\hline Number of people residing in the household & & & Yes & 476 & 99.6 \\
\hline$\leq 4$ & 159 & 33.3 & No & 2 & 0.4 \\
\hline $5-7$ & 278 & 58.2 & Electricity & & \\
\hline$>7$ & 41 & 8.6 & Yes & 471 & 98.5 \\
\hline Is there a maid or cleaner in the household? & & & No & 7 & 1.5 \\
\hline Yes & 39 & 8.2 & Roof & & \\
\hline No & 439 & 91.8 & Concrete slab & 79 & 16.5 \\
\hline Is the mother employed? & & & Ceramic tiles & 388 & 81.2 \\
\hline Yes & 224 & 48.5 & Others & 11 & 2.3 \\
\hline No & 240 & 44.2 & Flooring & & \\
\hline No information & 16 & 7.4 & Earthen/Simple cement & 107 & 22.4 \\
\hline Is the father employed? & & & Parquet/Hardwood & 13 & 2.7 \\
\hline Yes & 273 & 65.6 & Ceramic/Slate/Porcelain & 346 & 72.4 \\
\hline No & 96 & 23.5 & Others & 12 & 2.5 \\
\hline No information & 15 & 11.0 & Number of bedrooms & & \\
\hline Presence of trachoma & & & $\leq 2$ & 140 & 29.3 \\
\hline Yes & 30 & 6.3 & $>2$ & 338 & 70.7 \\
\hline
\end{tabular}

$\left(^{*}\right)$ No plastering, painting, flooring, and unfinished bathrooms.

TABLE 2: Characterization of the residences of students from the Jequitinhonha Valley region, Minas Gerais, Brazil, 2018

Sewage system

Yes

Bathroom inside the house

Yes

Electric shower

Yes 380

9.5

Water 
TABLE 3: Association between demographic and social variables and presence of trachoma in students living in the Jequitinhonha Valley, Minas Gerais, Brazil, 2018 (bivariate analysis).

\begin{tabular}{|c|c|c|c|c|c|}
\hline \multirow[t]{3}{*}{ Variables } & \multicolumn{4}{|c|}{ Trachoma } & \multirow[t]{3}{*}{ p-value* } \\
\hline & \multicolumn{2}{|c|}{ Yes } & \multicolumn{2}{|c|}{ No } & \\
\hline & (n) & $(\%)$ & $(n)$ & $(\%)$ & \\
\hline Gender & & & & & 0.661 \\
\hline Male & 13 & 43.3 & 176 & 39.3 & \\
\hline Female & 17 & 56.7 & 272 & 60.7 & \\
\hline Age & & & & & 0.558 \\
\hline$\leq 10$ years & 9 & 30.0 & 158 & 35.3 & \\
\hline$>10$ years & 21 & 70.0 & 290 & 64.7 & \\
\hline Current school grade & & & & & 0.965 \\
\hline $1^{\text {st }}$ to $5^{\text {th }}$ grade & 12 & 40.0 & 181 & 40.4 & \\
\hline $6^{\text {th }}$ to $9^{\text {th }}$ grade & 18 & 60.0 & 267 & 59.6 & \\
\hline Number of people residing in the household & & & & & 0.108 \\
\hline$\leq 4$ & 14 & 46.7 & 145 & 32.4 & \\
\hline$>4$ & 16 & 53.3 & 303 & 67.6 & \\
\hline Type of school & & & & & 0.008 \\
\hline Municipal & 18 & 60.0 & 161 & 35.9 & \\
\hline State & 12 & 40.0 & 287 & 64.1 & \\
\hline School location & & & & & $<0.001$ \\
\hline Rural area & 18 & 60.0 & 114 & 25.4 & \\
\hline Urban area & 12 & 40.0 & 334 & 74.6 & \\
\hline Is there a maid or cleaner in the household? (Fisher's exact test) & & & & & $0.497^{* *}$ \\
\hline No & 29 & 96.7 & 410 & 91.5 & \\
\hline Yes & 1 & 3.3 & 38 & 8.5 & \\
\hline Is the mother employed? & & & & & 0.437 \\
\hline No & 18 & 60.0 & 236 & 52.7 & \\
\hline Yes & 12 & 40.0 & 212 & 47.3 & \\
\hline Is the father employed? & & & & & 0.898 \\
\hline No & 7 & 23.3 & 100 & 22.3 & \\
\hline Yes & 23 & 76.7 & 348 & 77.7 & \\
\hline
\end{tabular}

$\left({ }^{*}\right)$ Chi-square test; $\left({ }^{* *}\right)$ Fisher's exact test.

Table 5 presents the final model of logistic regression analysis. The variables that were associated with the presence of trachoma were: living in a residence with no finishing, living in a residence without sewage system coverage, and studying in a rural area.

\section{DISCUSSION}

The prevalence of trachoma among students of the Jequitinhonha Valley was $6.3 \%$, which is slightly above the value of $5 \%$ recommended by $\mathrm{WHO}$ as indicative that the disease under control $^{1-3,7}$. The existence of trachoma in a population is an indicator of precarious living conditions, which also suggests the need for socioeconomic improvements ${ }^{1-3,7}$. Considering the vulnerable conditions of the evaluated population, this result should be taken as a warning sign since diagnosis may be neglected by health professionals, as there are few reports of the disease in the region.

In a survey conducted on 119,531 students and 1,156 municipalities in all regions of the country, an average trachoma prevalence of 5\% was identified. In Minas Gerais, the study recorded an average prevalence of $4.8 \%$, which is slightly below the results 
TABLE 4: Association between housing characteristics and presence of trachoma in students living in the Jequitinhonha Valley, Minas Gerais; 2018 (bivariate analysis).

\begin{tabular}{|c|c|c|c|c|c|}
\hline \multirow[t]{3}{*}{ Variables } & \multicolumn{4}{|c|}{ Trachoma } & \multirow[t]{3}{*}{ p-value* } \\
\hline & \multicolumn{2}{|c|}{ Yes } & \multicolumn{2}{|c|}{ No } & \\
\hline & (n) & $(\%)$ & $(n)$ & $(\%)$ & \\
\hline Type of property & & & & & 0.528 \\
\hline Rented/Living with relatives & 4 & 13.3 & 80 & 17.9 & \\
\hline Own property & 26 & 86.7 & 368 & 82.1 & \\
\hline Property Characteristics & & & & & 0.024 \\
\hline Finished house & 8 & 26.7 & 55 & 12.3 & \\
\hline Unfinished house ${ }^{* * *}$ & 22 & 73.3 & 393 & 87.7 & \\
\hline Sewage system & & & & & 0.001 \\
\hline No & 25 & 83.3 & 169 & 37.7 & \\
\hline Yes & 5 & 16.7 & 279 & 62.3 & \\
\hline Bathroom inside the house (Fisher) & & & & & $0.125^{\star *}$ \\
\hline No & 2 & 6.7 & 8 & 1.8 & \\
\hline Yes & 28 & 93.3 & 440 & 98.2 & \\
\hline Number of bedrooms & & & & & 0.117 \\
\hline$\leq 2$ & 5 & 16.7 & 135 & 30.1 & \\
\hline$>2$ & 25 & 83.3 & 313 & 70.7 & \\
\hline Flooring & & & & & 0.053 \\
\hline Earthen/Simple Cement & 11 & 36.7 & 96 & 21.4 & \\
\hline Others & 19 & 63.3 & 352 & 78.6 & \\
\hline Roof & & & & & 0.320 \\
\hline Ceramic tiles & 27 & 90.0 & 372 & 83.0 & \\
\hline Concrete slab & 3 & 10.0 & 76 & 17.0 & \\
\hline Electric shower & & & & & 0.692 \\
\hline No & 7 & 23.3 & 91 & 20.3 & \\
\hline Yes & 23 & 76.7 & 357 & 79.7 & \\
\hline
\end{tabular}

$\left({ }^{*}\right)$ Chi-square test; $\left({ }^{* *}\right)$ Fisher's exact test. $\left({ }^{* * *}\right)$ No plastering, painting, flooring, and unfinished bathrooms.

TABLE 5: Factors associated with the presence of trachoma in students living in the Jequitinhonha Valley, Minas Gerais; 2018 (multiple analysis by logistic regression).

\begin{tabular}{lc}
\hline Variable & p-value \\
\hline Property Characteristics & 0.027 \\
Unfinished house** $(95 \%$ Cl)* & $2.27(1.12-6.48)$ \\
Finished house & 1.0 \\
Sewerage system & $<0.001$ \\
No & 1.0 \\
Yes & 0.002 \\
School location & $3.49(3.52-25.60)$ \\
Rural area & $3.37(1.53-7.35)$ \\
Urban area & 1.0 \\
\hline
\end{tabular}

$\left.{ }^{*}\right)$ OR: Odds ratio; Cl: Confidence interval. ( $\left.{ }^{* *}\right)$ No plastering, painting, flooring, and unfinished bathrooms. 
reported in the present study ${ }^{9}$. This can be explained by the size and socio-economic differences between the populations studied. Similar to the current study, a significant difference was found between urban and rural students, the latter being most affected, while no significant difference was detected between males and females. However, unlike the present study, a higher prevalence was found among children under five years old ${ }^{9}$. This difference can be explained by the size and differences in the age groups of the populations studied.

A study on elementary school students from the state of Roraima, revealed an average prevalence of $4.5 \%$, a value below that found in this research. This can be explained by the similar socioeconomic characteristics among the populations studied. Among the studied variables, similar to this study, a significant difference between rural and urban area students was found and there was no significant difference between genders and between age groups ${ }^{10}$.

In a survey conducted on students from the city of Turmalina (in Minas Gerais), researchers found a trachoma prevalence of $4.7 \%$, slightly below the value found in the current study. This can be explained by the fact that this city, although part of the Jequitinhonha Valley, has better socioeconomic indices than most cities in the region. However, there was a statistically significant difference between rural and urban area students and no difference between genders ${ }^{12}$, which corroborated our findings.

The variables that were associated with the presence of trachoma in students, after multiple analysis, indicate mostly social exclusion, which is characterized by poverty and difficulty in accessing goods and services. Unfinished housing conditions probably reflect the family's financial struggle and, consequently, a low social and economic level.

The lack of adequate water waste treatment also denotes lack of access to social assets and poor housing conditions. In a systematic review study, Stocks et al. ${ }^{14}$ also evidenced the association between the presence of trachoma and poor sanitation. Regarding school location, a higher prevalence was identified in the rural area compared to the urban area, which is in accordance with the literature ${ }^{9,10,12}$. This finding might be linked to socioeconomic and sanitation conditions, which are usually worse in rural areas compared to urban regions.

Although age and gender were associated in other studies with trachoma, they were not statistically associated in the present study. Regarding age, previous studies verified a higher prevalence in younger children compared to older children ${ }^{9,10,15}$. This finding can be attributed to differences in sample size and the age group studied. Regarding gender, some studies showed a higher prevalence among women compared to $\operatorname{men}^{15,16,17}$. Some authors believe this may be due to females showing more affective behavior among themselves than males ${ }^{16,18}$.

The other variables studied, such as the presence of water, light, or showers, were not associated, which differed from other studies $^{15,17,19}$. These variables are not likely to have great relevance in the spread of the disease in the studied population.

Herein, the WHO criteria were used in the clinical diagnosis, which considers the clinical state with well-established signs of the disease as a positive result. Therefore, this could be a limiting factor to this study, as the identification of early cases might have been hindered. Moreover, a higher prevalence would be expected in preschool children, who were not evaluated.

Based on this study, considering that the presence of trachoma can be seen as an indicator of a population's socioeconomic conditions, the Jequitinhonha Valley needs government policies aimed at improving this situation, including basic sanitation and improvement in living conditions of the population, especially in rural areas.

\section{ACKNOWLEDGMENTS}

We offer our deepest thanks to the institutions that provided technical support for thedevelopment and implementation of this study.

\section{AUTHORS' CONTRIBUTION}

EJS: Substantial contribution to conception and design, acquisition of data, analysis and interpretation of data, drafting of the manuscript, critical revision of the manuscript for important intellectual content, statistical analysis, obtaining funding, administrative, technical, or material support supervision, and research group leadership; DPP, JOAMA, LMB and VLF: Acquisition of data, and drafting of the manuscript; APC: Substantial contribution to conception and design, analysis and interpretation of data, drafting of the manuscript, critical revision of the manuscript for important intellectual content, statistical analysis, administrative, technical, or material support supervision, and research group leadership. All authors have given final approval of the submitted manuscript.

\section{CONFLICTS OF INTEREST}

The authors have nothing to disclose.

\section{REFERENCES}

1. World Health Organization (WHO). Alliance for the Global elimination of trachoma by 2020: progress report on elimination of trachoma, 2014-2016. Genev: Weekly Epidemiological Record. 2017;26(92):359-68.

2. Taylor HR, Burton MJ, Haddad D, West S, Wright H. Trachoma. Lancet. 2014;384(9960):2142-52.

3. Araújo Silva MB, Andrade MS, de Oliveira YV, Santiago Marques MG, Mourão Pinho C, Araújo de Miranda Lopes K. Trachoma as cause of blindness: literature review. Int Arch Med. 2017;10.

4. World Health Organization (WHO). Planning for the global elimination of Trachoma (GET): report of a WHO Consultation Geneva. World Health Organization, 1997.

5. World Health Organization (WHO). 51 st World Healty Assembly, WHA51. World Health Organization 1998.

6. SchelliniSA,SousaRLF.Tracoma:aindaumaimportantecausadecegueira. Rev Bras Oftalmol. 2012;71:199-204.

7. Brasil. Manual de Controle do Tracoma. In: Saúde Md, editor. Brasília: Fundação Nacional de Saúde; 2014.

8. Canineo PA, Nishimira S, Medina NH, Koizumi IK, Cardoso MRA. Inqueérito Epidemiológico de tracoma em escolares no município de Embú das artes-SP. Arq Bras Oftalmol. 2012;75(4):264-6. 
9. Lopes MFC, Luna EJA, Medina NH, Cardoso MRA, Freitas HSdA, Koizumi IK, et al. Prevalência de tracoma entre escolares brasileiros. Rev Saude Publica. 2013;47:451-9.

10. Medina NH, Lopes MF, Durkin SR, Cardoso MR, Luna EA, Koizumi IK, et al. Survey of Trachoma within school students in the state of Roraima, Brazil. Ophthalmol. 2011;118(10):1938-43.

11. Ferraz LCB, Schellini SA, Padovani CR, Medina NH, Dalben I. Tracoma em crianças do ensino fundamental no município de Bauru: Estado de São Paulo, Brasil. Arq Bras Oftalmol. 2010;73(5):433-7.

12. Silva EJ, Oliveira LAV, Nasser LS, Leite LFA, Caldeira AP, Oliveira LCd. Prevalência de Tracoma em crianças em idade escolar no município de Turmalina, MG. Rev Bras Oftalmol. 2016;75(3):181-4.

13. Endi Lanza G, Emerson Cotta B, Delba Fonseca S. Análise da distribuição geográfica dos serviços de saúde no Vale do Jequitinhonha, Minas Gerais. Hygeia - Rev Bras Geo Med Saude. 2015;11(20)

14. Stocks ME, Ogden S, Haddad D, Addiss DG, McGuire C, Freeman MC. Effect of water, sanitation, and hygiene on the prevention of trachoma: a systematic review and meta-analysis. PLoS med. 2014;11(2):e1001605.
15. Oliveira MD. Situação epidemiológica do tracoma entre estudantes da rede pública de municípios do Piauí. Fundação Osvaldo Cruz: Escola Nacional de Saúde Pública Sergio Arouca; 2015.

16. Pinto ICS. Fatores epidemiológicos associados a prevalência de tracoma no estado do Amapá. Rio de Janeiro: Escola Nacional de Saúde Pública Sergio Arouca; 2011.

17. Alves FAP. Tracoma em Pernambuco: Análise das intervenções e dos fatores individuais e ambientais associados à ocorrência da doença. Fundação Osvaldo Cruz: Centro de Pesquisas Aggeu Magalhães; 2014.

18. Gambhir M, Basanez MG, Turner F, Kumaresan J, Grassly NC. Trachoma: transmission, infection, and control. Lancet Infect Dis. 2007;7(6):420-7.

19. D'Amaral RKK, Cardoso MRA, Medina NH, Cunha ICKO, Waldman EA. Fatores associados ao tracoma em área hipoendêmica da Região Sudeste, Brasil. Cad Saude Publica. 2005;21(6):1701-8. 